\title{
FORANE (COMPOUND 469): 3. COMPARATIVE EFFECTS OF PROLONGED ANAESTHESIA ON MATURE BEAGLE DOGS AND YOUNG RHESUS MONKEYS $\uparrow$
}

\author{
Peter H. Byles, M.B., B.S., Allen B. Dobkin, M.D. and David B. Jones, M.D.
}

"Pathology is not a pure science. The pathological changes are merely one side of the problem, of which the other is furnished by the clinical picture. Each throws light upon the other and neither is complete by itself." William Boyd, M.D. ${ }^{1}$

During THE DETALLed evaluation of Forane anaesthesia, fat droplets were observed in microscopic examination of the kidneys of rats and rabbits, and particularly in 5 female beagles that all received 15 hours ( 3 hours daily $\times 5$ ) of Forane anaesthesia. Fat was also observed in the kidneys of 5 rhesus monkeys that each had 16 hours ( 4 hours every other day $\times 4$ ) of Forane anaesthesia. At first, the pathologist attributed this to postmortem autolysis, which resembles cloudy swelling (with fat globules in the cytoplasm) and appears most commonly in the convoluted tubule of the kidney, ${ }^{1}$ but in fact the specimens were placed in formalin immediately to eliminate this possibility. The beagles and monkeys had liver biopsies done under barbiturate anaesthesia before any tests, and the microscopic examination of the liver in each case was normal. All liver sections of the beagles and the monkeys were also normal at postmortem except for a slight amount of fat in the liver of one monkey. ${ }^{2-4}$

After the initial liver biopsies, the animals picked at their stitches. This caused infections, which were treated with antibiotics. We later feared that the antibiotics might also have affected the kidneys and livers of these animals. ${ }^{5,6}$ Therefore, we decided to do a carefully controlled comparison of the effect of prolonged anaesthesia in 15 mature, 5-year-old, female, breeder beagle dogs and 25 young, rhesus monkeys. No infusions of electrolytes or other drugs would be given that might confuse the interpretation of the tests or examinations of the tissues, and organs would be removed promptly and placed in appropriate preservatives without delay, to avoid autolvsis.

\section{Methons}

Clinical procedures. Beagle dogs (mean weight $14.3 \mathrm{~kg}$ )

The 15 animals were examined, dewormed, given the necessary optimum care, and fed a high-protein diet for at least three weeks. They were then divided into 3 groups. Following inhalation induction by mask and endotracheal intubation, the dogs were maintained in a surgical plane of anaesthesia for 4-hour periods on alter-

*Trademark of Ohio Medical Products, Division of Air Reduction Co, Inc, Murray Hill, N.J.

†This work was supported by grants from the Division of Research Facilities and Resources of NIH through grant FR 00353 and by the Ohio Medical Products Division of Air Reduction Company, Inc, Madison, Wisconsin.

\$rom the Department of Anesthesiology and Department of Pathology, State University of New York, Upstate Medical Center, Syracuse, New York, 13210, U.S.A. 
nate days, for a total of 16 hours each. One group received 2.5 to 3 per cent Forane, the second group received 1.5 to 2.0 per cent halothane, and the third group received 1.0 to 1.5 per cent methoxyflurane. The anaesthetics were delivered with oxygen from calibrated vapourisers using a non-rebreathing system and allowing spontaneous breathing throughout. Arterial and venous blood samples and sterile catheter urine specimens were drawn just after induction of anaesthesia on the first test day and at the end of the final day's experiment. After the last anaesthetic, the abdomen was opened widely and the liver and kidneys were carefully examined grossly, then removed, promptly placed in a preservative, and sent to the pathologist with an identifying number not indicating the anaesthetic received by that animal. Representative biopsy specimens were taken from each organ and permanent sections were made, using haematoxolin/eosin and Sudan iv stains.

\section{Laboratory procedures}

To evaluate the kidney and liver functions, we decided to select only those tests that might give us the maximum clinical data without requiring injection of foreign compounds or drawing an appreciable amount of blood from the animal. ${ }^{7,8}$

In the female beagle dogs, it was decided that a careful urinalysis should be done at the beginning and then after the anaesthetic tests. This might give us a clue to the functional integrity of the kidney. A sterile catheter was used to collect a "midstream" specimen after a 12-hour fast whenever possible. The urine was examined as to colour, odour, $\mathrm{pH}$, and specific gravity. A microscopic examination of centrifuged resuspended urine sediment was done to seek the presence of yeast, crystals, fat bodies or casts, and blood cells. A gram stain was done on a drop of urine to seek bacteria. Sensitive quantitative chemical tests were done for the presence of protein and glucose. Urine bilirubin, acetone, and haemoglobin were identified with reagent tablets and other appropriate tests.

The blood samples were drawn as in previous studies to measure creatinine and blood urea nitrogen, recognizing that the creatinine would remain normal unless renal clearance was seriously reduced, and that BUN is neither specific nor sensitive enough to increase above the normal range ( 7 to $20 \mathrm{mg}$ per cent) until the glomerular filtration rate had declined at least 50 per cent. However, we felt that, since the animals were on a balanced protein diet and hydration was maintained before and between the tests, changes in the BUN might also indicate altered liver function.

Prothrombin time and transaminases were measured because the latter (especially SGPT) are believed to be the most sensitive indicators of liver cell damage. The remaining laboratory tests - serum potassium, whole blood lactate and pyruvate, blood sugar, non-esterfied fatty acids, and plasma cortisol - were considered appropriate monitors of metabolic functions with the minimum volume requirement for blood samples. Arterial blood gases and $\mathrm{pH}$ were measured serially to determine whether respiration was adequate.

\section{Results}

\section{Clinical observations}

There was some excitement while inducing anaesthesia by mask in the beagles because they were untrained for laboratory study and hence were suspicious and 
resistant. However, once induced, anaesthesia was smooth with all agents. Recovery was fastest with Forane and slowest with methoxyflurane. All the animals looked well and took food readily an hour or two after Forane and halothane, and somewhat later after methoxyflurane anaesthesia.

Table $I$ is a summary of the blood chemistry tests.

There was very little spread in the values for individual animals and, aside from a slight decrease in serum potassium, the Bun, creatinine, prothrombin time, transaminases, and free fatty acids were within the normal range and showed no significant changes with any of the agents. The blood lactate, pyruvate, sugar, and plasma cortisol were elevated initially, probably due to excitement caused by mask induction. These laboratory values of course do not indicate the individual alterations that occurred with each test, but only the over-all change from the beginning (before any anaesthesia) to the end (after the last test). Although the plasma cortisol and blood sugar decreased gradually between each test, they probably rose during the tests, as we saw in our preceding studies. ${ }^{2-4}$ In any case, they were in the normal range at the end in spite of the considerable exposure to anaesthesia over a one-week period.

Serial blood gases showed that all the dogs were well-oxygenated and were ventilating adequately during maintenance, except in the methoxyflurane series in which the $\mathrm{PaCO}_{2}$ values at the end were in the range of 47 to 70 torr. A slight metabolic acidosis was usual in the control bloods (due to overnight fasting) and did not change substantially during the tests.

The urinalysis reports indicated that there was preexisting renal dysfunction in all the beagles since proteinuria, bilirubinuria, and various amorphous casts were common in the control urine samples, but there were no glucose, acetone, haemoglobin, or bacteria present. The $\mathrm{pH}$ varied (acid and alkaline). Specific gravity was usually over 1025 , indicating that the kidneys concentrated the urine well enough that one could safely say tubular function was normal.

After all three anaesthetics were given for 16 hours, the final urine samples revealed fat droplets on microscopic examination. One might be inclined to retire at this point and state, without reservation, that these anaesthetics were undoubtedly toxic to the kidney parenchyma, but we remembered an old writer's remarks: "The good physician trusteth not the simple witness of the water if better testimony be had. For reasons drawn from the urine alone are as brittle as the urinal."1 Hence, we awaited the pathologist's observations and opinion.

\section{Pathology}

Grossly, the liver and kidneys did not appear to be unusually fatty. They were neither enlarged nor unusually soft, and did not present a greasy cut surface. However, the microscopic examinations showed that fat was indeed present in all the kidney specimens. Some fat was also seen in the livers of the animals that received Forane and halothane, and cloudy swelling or hydrops of the liver was seen in dogs from all three groups. In the kidney, the fat was confined to the loop of Henle (see Table II and Figures 1, 2,3).

The data of all the laboratory tests were reviewed with the pathologist and we concluded that there was some doubt that the liver and kidneys of these mature, female, beagle dogs were invariably normal at the outset of the experiment, even 


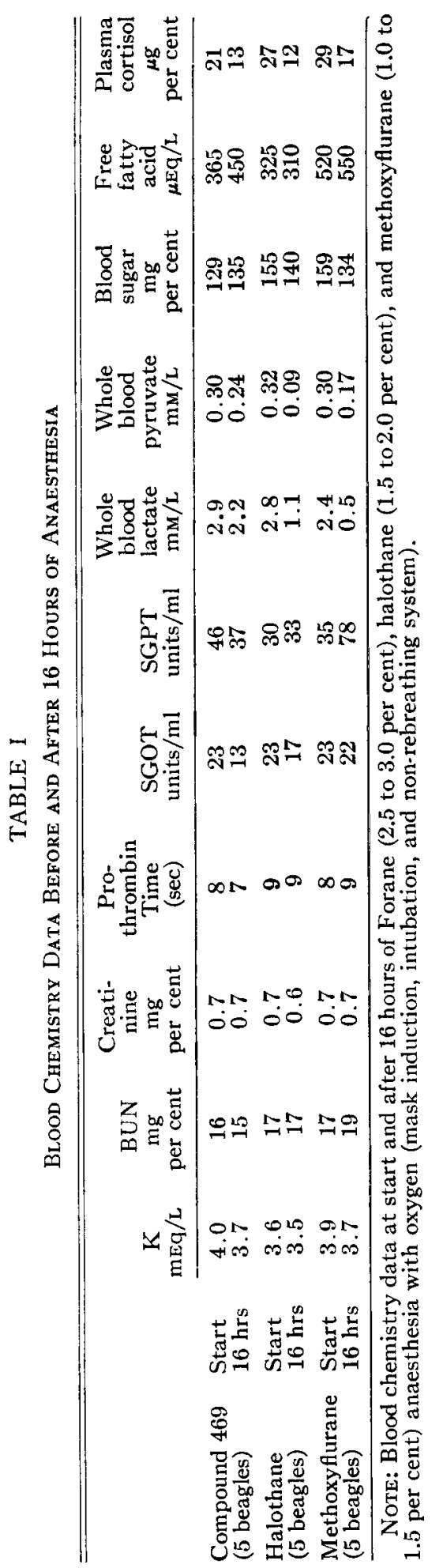


TABLE II

Organ Toxicity Study of Compound 469 (Forane)

(Microscopic pathology - Sudan IV and $\mathrm{H} \& \mathrm{E}$ Stained after 4 hours of anaesthesia every other day $\times 4$ )

\begin{tabular}{lcccc}
\hline & $\begin{array}{c}\text { Beagle } \\
\text { dogs }\end{array}$ & Hydrops & Fat & $\begin{array}{c}\text { Kidney } \\
\text { Fat }\end{array}$ \\
\cline { 2 - 5 } & 1 & + & 0 & + \\
Compound 469 & 2 & + & 0 & + \\
2.5 to 3 per cent & 3 & ++ & 0 & ++ \\
& 4 & 0 & ++ & +++ \\
& 5 & ++ & + & +++ \\
Halothane & 1 & ++ & 0 & ++ \\
1.5 to 2 per cent & 2 & 0 & +++ & ++ \\
& 4 & \pm & 0 & +++ \\
& 5 & \pm & 0 & + \\
Methoxyflurane & 1 & + & 0 & ++ \\
1.0 to 1.5 per cent & 2 & +++ & 0 & ++ \\
& 3 & +++ & 0 & +++ \\
& 4 & +++ & 0 & +++ \\
& 5 & +++ & 0 & ++ \\
\hline
\end{tabular}

though no fat was found in the urine initially. The proteinuria and the somewhat elevated BuN observed initially indicated that the kidneys were certainly not normal even though the creatinine was not elevated.

In dogs, liver function tests will not usually show evidence of damage until the portal blood flow is substantially decreased due to excessive lipidosis, or until secondary hepatic necrosis occurs. ${ }^{1,7,8}$ At this stage, icterus and an enlarged, tender liver have usually supervened, and gross examination literally shows the tissue to be distended with fat so that the liver structure is barely discernible. This was not seen in these animals. The transaminases (especially SGPT) are very sensitive indicators of damage to hepatic cells and they did not show any appreciable change, except with a relatively high concentration of methoxyflurane. It was, therefore, likely that in these beagles the livers were functionally and anatomically relatively normal as compared to the kidneys. We concluded that data obtained from the mature, breeder, female, beagles were probably not conclusive tests of the safety of inhalational anaesthetics as far as kidney function is concerned. The mild pathological changes found in the liver sections were not sufficient to produce detectable alterations in hepatic function tests.

\section{Rhesus monkeys ( 3.5 to $4.0 \mathrm{~kg}$ )}

After a period of observation as before, a control venous blood sample was drawn from each of twenty-five rhesus monkeys and they were randomly divided into five groups of five; one group to receive each of the anaesthetic agents: Forane, Ethrane ${ }^{*}$, methoxyflurane, and halothane. The fifth group was used as a control and received no anaesthesia, while the other four groups were anaesthetized for four hours a day, on alternate days, for a total of 16 hours of anaesthesia. The pathologist involved in the study (DBJ) was not apprised of which monkeys received any of the agents or no anaesthesia.

Smooth induction of anaesthesia was accomplished by placing the monkey (in

"Trademark of Ohio Medical Products, Division of Air Reduction Co, Inc, Murray Hill, N.J. 
TABLE III

Rhesus Monkey Study

(4 hours' anaesthesia every other day $\times 4$ )

\begin{tabular}{|c|c|c|c|c|c|c|c|c|}
\hline \multirow[b]{2}{*}{$\begin{array}{l}\text { A Compound } 469 \\
\text { B Ethrane } \\
\text { C Halothane } \\
\text { D Methoxyflurane } \\
\text { E No Anaesthesia }\end{array}$} & \multicolumn{2}{|c|}{$\begin{array}{l}\text { Day } 1 \\
\text { No. of } \\
\text { Hrs. Animals }\end{array}$} & \multicolumn{2}{|c|}{$\begin{array}{l}\text { Day } 2 \\
\text { No. of } \\
\text { Hrs. Animals }\end{array}$} & \multicolumn{2}{|c|}{$\begin{array}{l}\text { Day } 3 \\
\text { No. of } \\
\text { Hrs. Animals }\end{array}$} & \multicolumn{2}{|c|}{$\begin{array}{c}\text { Day } 4 \\
\text { No. of } \\
\text { Hrs. Animals }\end{array}$} \\
\hline & $\begin{array}{l}4 \\
4 \\
4 \\
4\end{array}$ & $\begin{array}{l}5 \\
5 \\
5 \\
5 \\
5\end{array}$ & $\begin{array}{l}8 \\
8 \\
8 \\
8\end{array}$ & $\begin{array}{l}4 \\
4 \\
4 \\
4 \\
4\end{array}$ & $\begin{array}{l}12 \\
12 \\
12 \\
12\end{array}$ & $\begin{array}{l}3 \\
3 \\
3 \\
3 \\
3\end{array}$ & $\begin{array}{l}16 \\
16 \\
16 \\
16\end{array}$ & $\begin{array}{l}2 \\
2 \\
2 \\
2 \\
2\end{array}$ \\
\hline
\end{tabular}

its cage) in a box containing approximately $3 \mathrm{MAC}$ of the agent, until unconsciousness appeared evident. It was then quickly removed, anaesthesia was deepened by mask to a surgical plane and an endotracheal tube inserted and attached to a nonrebreathing circuit, allowing spontaneous breathing. The ambient temperature was kept at 85 to $90^{\circ} \mathrm{F}$ and each animal's temperature was monitored.

Maintenance of anaesthesia was as described for the beagles. The mean concentrations of the agents required to maintain surgical anaesthesia were: Forane 1.5 to 2.5 per cent, Ethrane 1.5 to 2.0 per cent, methoxyllurane 0.5 to 0.7 per cent (progressively diminishing throughout each four-hour period), and halothane 1.0 to 1.25 per cent. No premedication drugs, barbiturates, muscle relaxants, or nitrous oxide were used.

On each of the first three days of the experiment, a venous blood sample was drawn from one monkey in each group, including the control group, at the beginning and end of the four hours of anaesthesia. These monkeys were then sacrificed by intracardiac injection of a barbiturate. The liver and kidney were taken quickly and placed in a preservative for subsequent gross and microscopic examination. At the end of the fourth day of anaesthesia, the same procedure was followed with the two remaining animals in each group. Table III shows the cumulative hours of anaesthesia and the numbers of surviving monkeys on each day.

All the blood samples were assayed for blood urea nitrogen, serum creatinine, and SGPT, and the results were examined for evidence of either acute changes during the course of each four-hour anaesthetic or chronic or progressive changes over the total period of the experiment.

\section{Results}

The blood chemistry measurements did not reveal any significant short- or longterm changes, nor were there significant differences found between any of the five groups of monkeys ( Table IV).

The tissue slices were stained with haematoxolin and eosin and with Sudan rv. All kidney sections were free of gross and microscopic pathology. No fat droplets or oxalate crystals were observed in the kidney tubules.

In the liver sections, changes were observed in four monkeys, as follows:

One animal, after 12 hours of methoxyllurane, had cloudy swelling and a considerable amount of fat diffusely spread through the liver cells. Another, after 16 hours of methoxyflurane, had cloudy swelling and a small amount of fat (early fat 


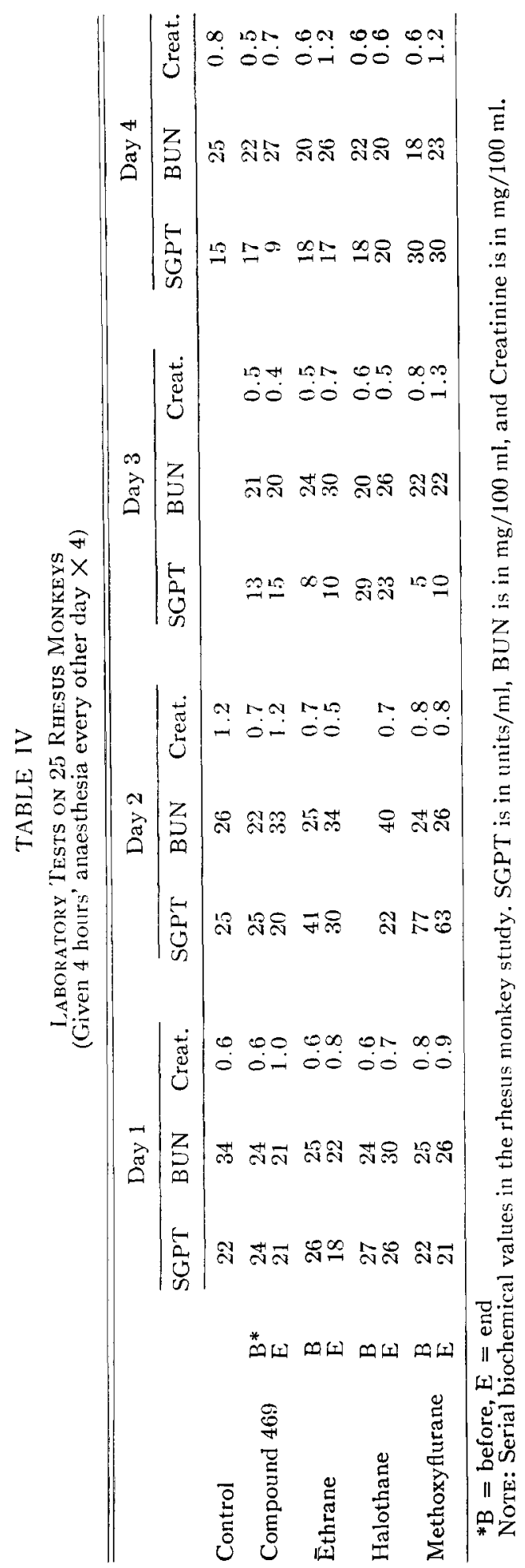


deposits). One animal, after 4 hours of Ethrane anaesthesia, had some fat around the veins of the liver, while another animal, after 12 hours of Forane anaesthesia, had a slight amount of fat in the liver.

All remaining liver sections were described as normal.

\section{Discussion}

The primary purpose of this group of experiments was to examine in the proper perspective an abnormal finding that was noted in our previous evaluations of Forane anaesthesia. To wit, was the observation of fat droplets in the microscopic sections of the kidney, in several animal species, after prolonged anaesthesia, due to a specific effect of Forane? If so, is this the only halogenated anaesthetic agent that causes such an effect? And, if this effect is common with several anaesthetics, is it something we should be concerned about? Finally, how can we, perhaps, keep such an effect to a minimum?

Questions of this type demand careful answers, more perhaps in the evaluation of new anaesthetic compounds than of any other category of drugs.

There is little doubt in our minds that the appearance of fat in the kidney tubules and fat droplets in the urine can occur when deep Forane anaesthesia is given for several hours. It appears to be most likely to occur regularly in mature female animals that have evidence of some renal impairment at the outset, but fat may also appear in the kidneys of male dogs who are apparently fit but have been exposed to several deep anaesthetics with different halogenated agents at relatively short intervals. ${ }^{2-4}$

The crossover study, as well as the preceding experiments, clearly showed that Forane anaesthesia is not the only halogenated anaesthetic that may cause this pathological effect, as it was seen with halothane, and was particularly noticeable with methoxyflurane..$^{2-4}$

Since halothane and methoxyflurane appear to have the same effect on the kidney as Forane, what are the clinical implications? Halothane has been administered to millions of humans without any significant evidence of a toxic effect on the kidney and when properly given a deleterious effect on the liver is highly unlikely. Methoxyflurane has, on rare occasions, been said to have caused clinical evidence of renal dysfunction after prolonged anaesthesia in elderly hypertensive or diabetic patients, but such an effect has virtually never been seen or reported in obstetrical or pediatric patients. ${ }^{9,10}$ It therefore appears that this pathological renal effect is a very slight risk to be considered only in the elderly patient who may have underlying renal disease, just as it may occur with many antibiotics, other therapeutic agents, and the degenerative changes of advancing age. . $^{1,5,6}$

In the same context, we must consider that there are two main causes of fatty metamorphosis: the action of toxins (bacteria, drugs, and ethanol) and the effect of hypoxia. In humans, it is most commonly seen in the liver, kidney, and heart, especially among elderly obese females. Chronic infections, chronic alcohol intake, anaemia, and atrophic changes of old age make the fat droplets in these organs much larger and more numerous. In animals, a high fat-low protein diet will cause similar effects. Unfortunately, anaesthetics must often be given when there may 
already exist or be underlying conditions which promote the development of fatty infiltration. ${ }^{1}$

The method by which an anaesthetic is given, and the physical status of the subject to whom it is administered, both play a crucial role in the physiological, biochemical, and tissue responses to it, both in animals and man. Provided that further study in man with Forane anaesthesia does not reveal any significant drawbacks, it should have considerable usefulness. In view of the fact that Forane has a relatively low fat solubility and a low water solubility, it is probably less likely to have as much effect on parenchymatous tissues as either halothane or methoxyflurane. Nevertheless, the possibility of adverse tissue effects should be minimised clinically from the very outset by using Forane judiciously: in long cases, induction of anaesthesia should be with other agents such as thiopentone and a non-depolarizing muscle relaxant. Maintenance should include nitrous oxide ( 50 to 70 per cent) so that the inhaled concentration of Forane need not exceed 1.5 to 2.0 per cent for more than 30 minutes. ${ }^{11}$ Needless to say, it should be dispensed from a properly calibrated vapouriser and pulmonary ventilation should be augmented to a normal level at all times. Only by such cautious measures can we ensure the bencfits of modern pharmacology and avoid aggravating the hysterical climate of public opinion about drugs.

\section{Summary and Conclusions}

Three groups of 5 ( 5 -year-old) mature, breeder, beagle dogs were given 4 hours of anaesthesia on alternate days, four times each with Compound 469 (Forane) 2.5 to 3 per cent, halothane 1.5 to 2.0 per cent, and methoxyflurane 1.0 to 1.5 per cent. Fat was seen in the loop of Henle of the kidney to a variable degree in all animals. Three animals had some fat in the liver, as well. This observation, together with the preceding proteinuria and elevation of the blood urea nitrogen, indicated that these animals probably had pathological alterations beforehand. Nevertheless, they tolerated the anaesthetics well.

The safety of the halogenated agents was further evident from the effects noted in 4 groups of 5 rhesus monkeys which received Forane, Ethrane, halothane, and methoxyflurane. After 4 to 16 hours of anaesthesia with these agents, the pathologist could not distinguish the liver and kidneys and their microscopic sections from those of 5 rhesus monkeys that had not received any anaesthesia. Laboratory tests (SGOT, BIN, and Creatinine) in these monkeys did not show any significant changes.

We have now studied Forane as a prospective new clinical anaesthetic, so that we could answer the two vital questions, viz., is the agent effective and is it safe? This investigation together with the preceding two reports, and initial studies in several animal species, corroborated our impression that this agent would be effective, safe, and probably at least as useful as similar agents now in widespread clinical use.

For the following cogent reasons, we recommend its trial in man: it is nonexplosive, chemically stable, and has a hardly perceptible odour. It does not cause vagal, salivary, or neuromuscular stimulation or seizure activity during surgical anaesthesia, and liver function tests, urine output and microscopic studies of the 
liver and kidney - after 15 to 16 hours of anaesthesia within one week - did not show appreciable deleterious effects different to, or worse than, halothane and methoxyflurane. It has relatively strong analgesic and muscle relaxing properties and has a moderately potent hypnotic effect. Moreover, it is rapid acting, i.e., induction and emergence are smooth and rapid, without electrocardiographic changes and only transient cardiovascular depression (due to its rapid uptake). Our tests showed that it was compatible with muscle relaxants and appeared to be relatively safe with a small dose of very dilute epinephrine. Biochemical tests were also relatively unaffected and changes in blood sugar, catecholamines and plasma cortisol appeared to show the responses to stress were unimpaired even after prolonged anaesthesia.

This series of experiments indicated that Forane is not contraindicated for trial in man.

Based on the laboratory and pathological evidence and subsequent corroboration from another investigator, we elected to proceed with a clinical evaluation.

\section{RÉSUMÉ}

Trois groupes de 5 bigles, femelles, adultes, âgées de 5 ans, ont reçu, tous les deux jours pendant 4 heures quatre fois une anesthésie soit à l'agent 469 (Forane) à 2.5-3 pour cent, soit au halothane à 1.5-2 pour cent soit méthoxyflurane 1.01.5 pour cent.

Chez tous les animaux on a trouvé de la graisse, à un degré variable dans l'anse de Henlé du rein; trois chiens avaient de la graisse aussi dans le foie.

Cette observation, ainsi que la protéinurie précédente et l'élévation de l'azote de l'urée sanguine, indiquait que ces animaux avaient probablement des lésions pathologiques auparavant. Néanmoins, ils ont bien toléré les anesthésies.

La sûreté des agents halogènes a été de plus démontrée par les effets notés dans 4 groupes de 5 singes rhésus qui ont reçu Forane, enflurane, halothane et méthoxyflurane. Après 4 à 16 heures d'anesthésie avec ces agents le pathologiste ne pouvait pas distinguer le foie, les reins et leurs coupes microscopiques de ceux des 5 singes qui n'avaient reçu aucune anesthésie. Les tests de laboratoire (sGot, azote de lurée sanguine et créatinine) chez ces singes n'ont pas montré de changements pathologiques significatifs.

Nous avons aussi étudié le Forane comme un futur agent anesthésique clinique, afin de pouvoir répondre à deux questions importantes: cet agent est-il efficace et est-il sûr?

Cette étude, ainsi que les deux publications précédentes, et aussi les expériences préliminaires faites sur différentes espèces d'animaux, ont corroboré notre impression que cet agent anesthésique pourrait être efficace, sûr et probablement au moins aussi utile que d'autres agents similaires actuellement largement cliniquement employés.

Nous recommandons qu'il soit essayé chez l'homme pour les raisons indiscutables suivantes: il est non-explosif, il est chimiquement stable et il n'a presque pas d'odeur. Pendant l'anesthésie chirurgicale il ne cause pas de stimulation ni du nerf vague, ni des glandes salivaires, ni neuromusculaire et ne provoque pas d'ac- 
tivité convulsive. Les tests fonctionnels hépatiques, la quantité d'urine et les examens microscopiques du foie et des reins - après 15 à 16 heures d'anesthésie au cours d'une semaine - n'ont pas montré d'effets nocifs différents ou pires que ceux du halothane ou du méthoxyflurane. Il a des propriétés analgesiques relativement fortes et produit aussi un relâchement musculaire, son effet hypnotique est modérément puissant. De plus, il a une action rapide, c.a.d. l'induction et le réveil sont doux et rapides, sans changements électrocardiographiques, mais une dépression cardiovasculaire passagère (due à l'absorption rapide). Il était compatible avec les myorésolutifs et il semblait être relativement sans danger avec une petite dose d'épinéphrine très diluée. Les tests biochimiques étaient relativement normaux et les changements du sucre sanguin, des catécholamines et du cortisol du plasma semblaient montrer que les réactions au stress n'étaient pas affectées même après une anesthésie prolongée.

Cette série d'expériences démontre que Forane n'est pas contreindiqué pour des essais chez l'homme.

En nous basant sur les données du laboratoire et sur les évidences pathologiques (corroborées par un autre investigateur), nous avons décidé de procéder à une évaluation clinique.

\section{REFERENCES}

1. Boyd, William. A Textbook of Pathology. 5th ed. Philadelphia: Lea \& Febiger (1947).

2. Dobkin, A. B. \& BYLEs, P. H. Laboratory evaluation of 1-chloro 2,2,2-trifluoroethyl difluromethyl ether (Compound 469). Unpublished reports filed with Air Reduction Co, Inc (1969).

3. Byles, P. H.; Dobkin, A. B.; Ferguson, J. H.; \& Levy, A. A. Forane (Compound 469): 1. Crossover comparison with enflurane (Ethrane), halothane, and methoxyflurane in dogs. Canad. Anaesth. Soc. J., 18:4 (1971).

4. Brles, P. H.; Dubkin, A. B.; Ferguson, J. H.; \& Levy, A. A. Forane (Compound 469): 2. Biochemical effects of repeated administration to animals, the response to bleeding, and its compatibility with epinephrine. Canad. Anaesth. Soc. J., 18:4 (1971).

5. Schreiner, G. E. Toxic nephropathy. J.A.M.A., 191:849 (1965).

6. Schreiner, G. E. \& Maher, J. F. Drugs and the kidney. Ann. N.Y. Acad. Sci., 123:326 (1965).

7. Shrrlock, Sheila A. Diseases of the liver and biliary system. 4th ed. Oxford, Blackwell Scientific Publications ( 1968 ).

8. Shein, P. S.; Davis, R. D.; Carter, S.; Newman, J.; Shein, D. R.; \& Rall, D. P. The evaluation of anticancer drugs in dogs and monkeys for the prediction of qualitative toxicities in man. Clin. Pharmacol. \& Therap., 11:3 (1970).

9. Lapointe, A. \& Bele-Binda, N. Nephrotoxicité associée au methoxyflurane. Canad. Anaesth. Soc. J., 17:145 (1970).

10. Crandell, W. B. \& MacDonald, A. Nephropathy associated with methoxyflurane anesthesia: follow-up report. J.A.M.A., 205:798 (1968).

11. Dobkin, A. B.; Byles, P. H.; Granooni, S.; \& Valbuena, D. A. Clinical and laboratory evaluation of a new inhalation anaesthetic: Forane (Compound 469 ), $\mathrm{CHF}_{2}-\mathrm{O}-\mathrm{CHClCF}_{3}$ (1-chloro-2,2,2-trifluoroethyl difluoromethyl ether). Canad. Anaesth. Soc. J., 18:264 (1971). 

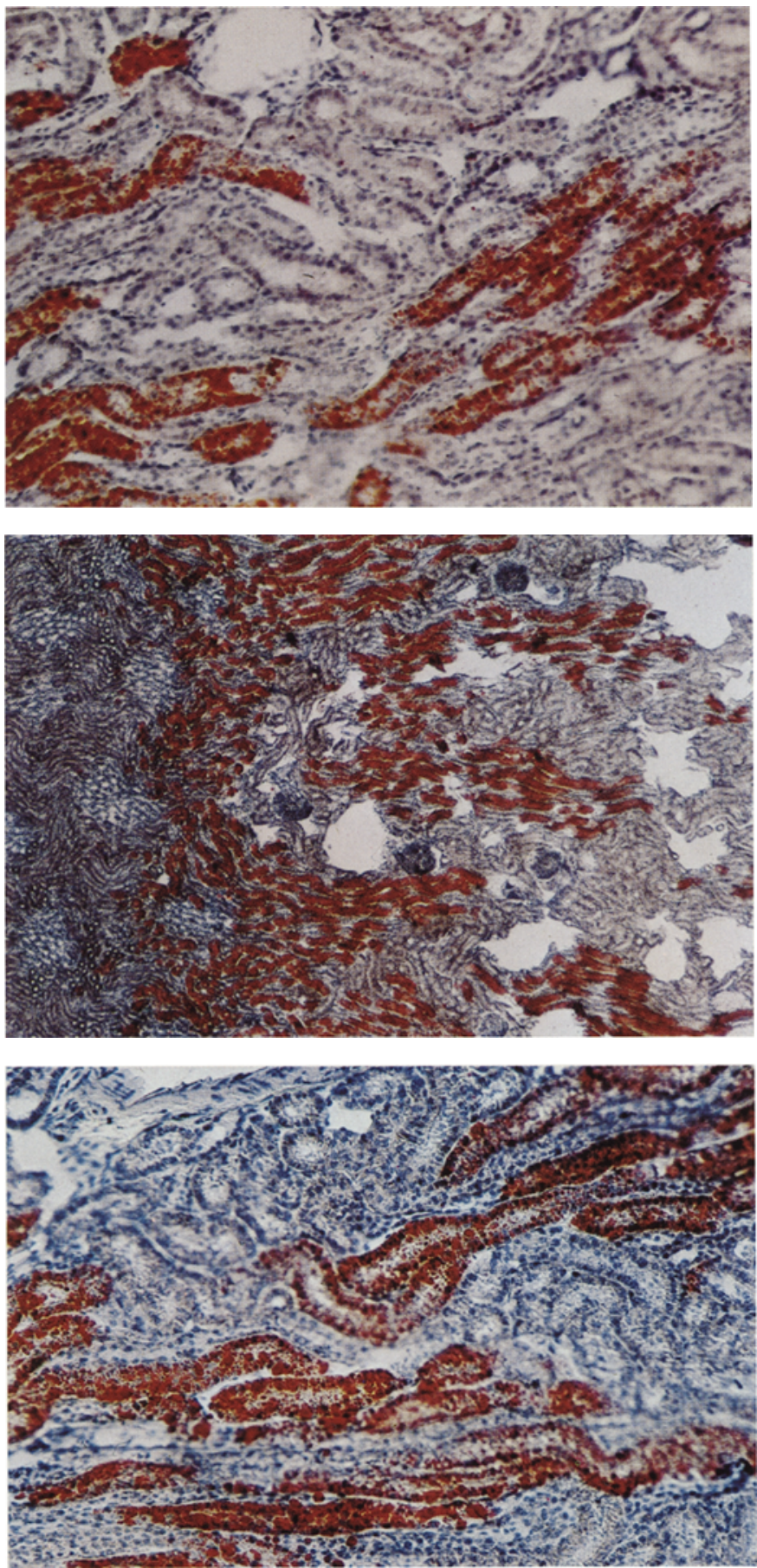

Figure 1. Fat droplets in kidney tubules of beagle after 16 hours Forane anaesthesia. ( 2.5 to 3.0 per cent) Sudan iv stain $\times 450$

Figure 2. Fat droplets in kidney tubules of beagle after 16 hours halothane anaesthesia. (1.5 to 2.0 per cent) Sudan IV stain $\times 100$
Figure 3. Fat droplets in kidney tubules of beagle after 16 hours methoxyflurane anaesthesia. (1.0 to 1.5 per cent) Sudan IV stain 